\title{
Distribution of Ostracods in the Groundwater of the North Western Coast of Euboea (Greece)
}

\author{
Dan L. Danielopol*
}

\begin{abstract}
SUMMARY
Freshwater fauna from 20 wells located $15-200 \mathrm{~m}$ from the seashore as well as marine interstitial fauna from the coastal zone around the village Aghios Georghios (Cape Likhada) have been investigated. Freshwater hypogean ostracods live mainly in protected wells having clean bottom and little particulate organic matter from which the water is moderately pumped. Epigean freshwater ostracods dominate in unprotected wells with large amounts of organic matter on the bottom. There is a sharp difference between the ostracod fauna living in fresh groundwater (mainly Cypridids) and those living in coastal marine interstitial habitats (marine Cytherids and Polycopids).

It is suggested that in the Mediterranean realm the hypogean fauna could be found easily in protected wells with little organic matter accumulation, where water is moderately pumped.
\end{abstract}

\section{INTRODUCTION}

The scarce information on freshwater interstitial fauna of Greece has recently been reviewed by Bou (1975) and Matsakis (1975). Bou visited Greece during 1969 and 1971 and extensively sampled hypogean fauna (see his report, 1975). Prior to 1969 , Schäfer (1945) and Stephanides (1948) sampled fauna from wells, the former collected in Thessaly around Carla Lake at about 25$40 \mathrm{~km}$ in from the sea coast; the latter investigated several wells in Corfu Island. Schäfer found a rich hypogean ostracod fauna and also reported (1951) that some of the well fauna from Thessaly came from a limestone area. Therefore it was not clear if Schäffer's ostracods live in a porous aquifer or in a karstic one. Considering the typical interstitial fauna accompaning the ostracods from Thessaly (Microcharon (Isopoda), Parastenocaris, Sigmatidium (Harpacticoida) as well as the minute size of ostracods belonging to the genera Kliella, Nannokliella and Mixtacandona (see Schäfer, 1945), I hypothesized (1971 and 1977) that the ostracods should be interstitial inhabitants. Stephanides (1948), quite opposed to Schäfer, found only epigean fauna in the wells of Corfu.

Bou offered me the ostracods he collected in many wells in Greece, and I found that, in addition to the well samples containing blind hypogean ostracods, there were also some samples in which epigean fauna dominated. In or-

* Limnologisches Institut, Berggasse 18, A-1090 Wien. 


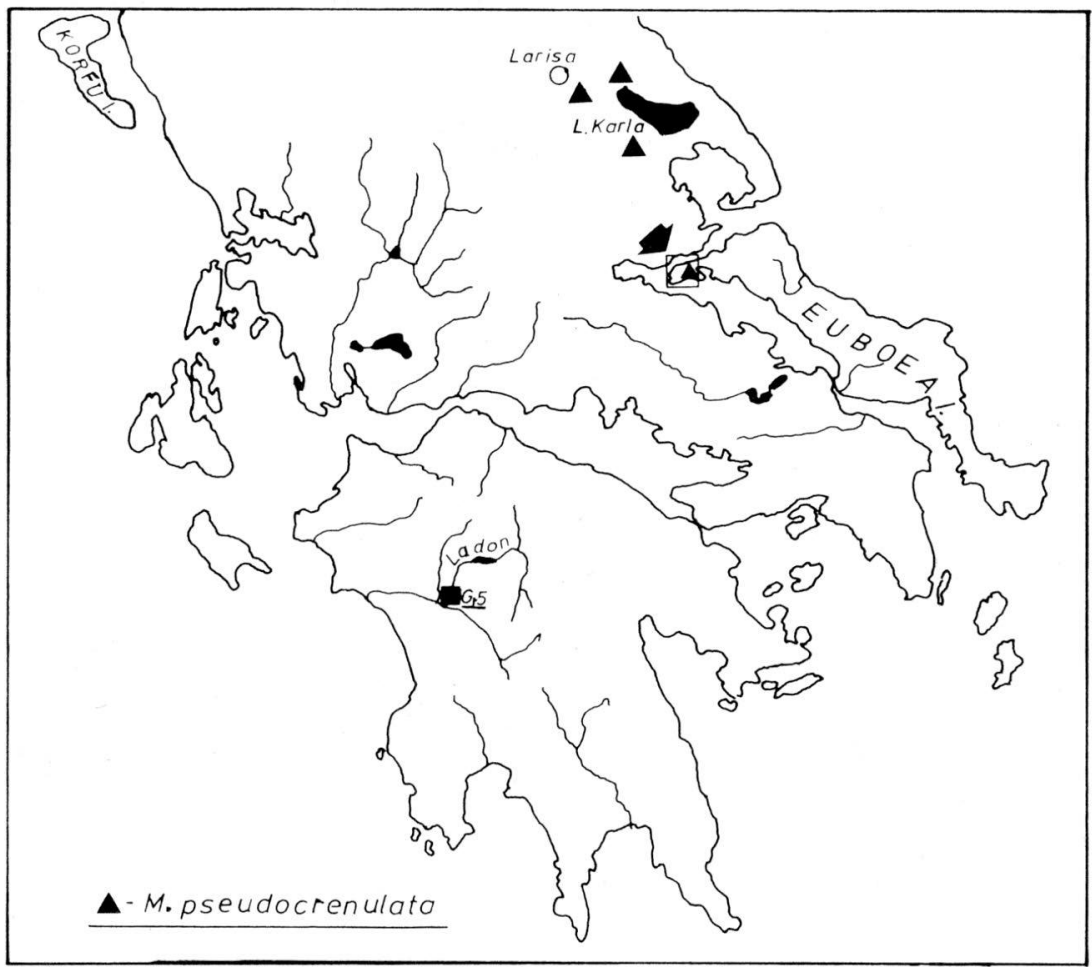

Fig. 1. General view of Greece. The arrow indicates the northwestern coast of Euboea where the interstitial fauna was investigated in 1976. The triangle indicates the distribution of Mixtacandona pseudocrenulata Schäfer. The square indicates the station Greece 5 on the Ladon Valley (see Bou, 1975).

der to explain these faunistic differences, I hypothesized that the wells where epigean fauna dominated are polluted and hence unfavorable for hypogeans.

During the latter part of August and early September, 1976, I visited Greece in order to verify this hypothesis and tried to verify some of the ostracod species found by Schäfer. A report on a new freshwater ostracod of marine origin found in Greece has been presented elsewhere (Danielopol, 1979).

The strategy of my sampling program was different from that of Bou, who extensively collected fauna over a large territory (see figure 1 in his 1975 report). I decided to investigate a restricted area along the northwestern coast of Euboea Island (fig. 1 and 2) around the village Aghios Georghios Likhadas and the Biological Station Keramou. From the data of Bou $(1974,1975)$, Coineau (1969), and Matsakis (1975), I knew that the wells in this area have a diverse fauna. 


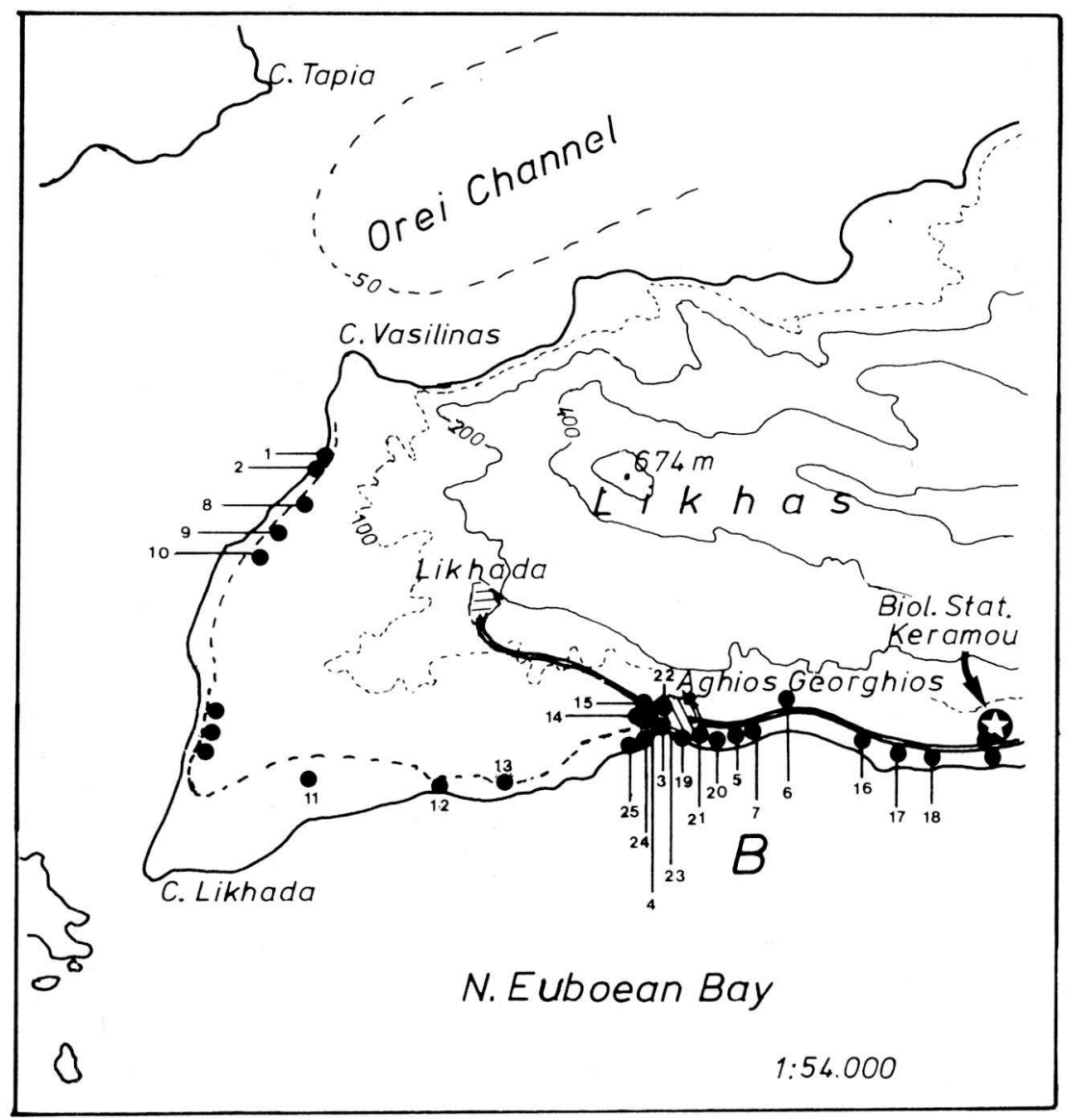

Fig. 2. The northwestern part of Euboea near the village Aghios Georghios and the Biological Station Keramou. 1-24 are the sample sites mentioned in table 1. The isobath - 50m in the Orei channel - drawn after Yannopoulos and Barrois (1975).

THE SAMPLING AREA (fig. 1, 2, 3, table 1)

The northwestern part of Euboea is dominated by the limestone rocks of the mountain Likhas (674 m altitude). On the western side of the Island (Zone B, fig. 2), the lowland is extremely reduced (about $300 \mathrm{~m}$ width). On the northern part between Cape Likhada and Cape Vasilinas (Zone A, fig. 2), the plain becomes wider. A porous aquifer exists in the coastal lowland which supplies the water needed by the inhabitants. I had the opportunity to examine the sediment extracted from a borehole during the construction of well number 18. It was mainly sand with marine fossils (spicules of sponge). In 


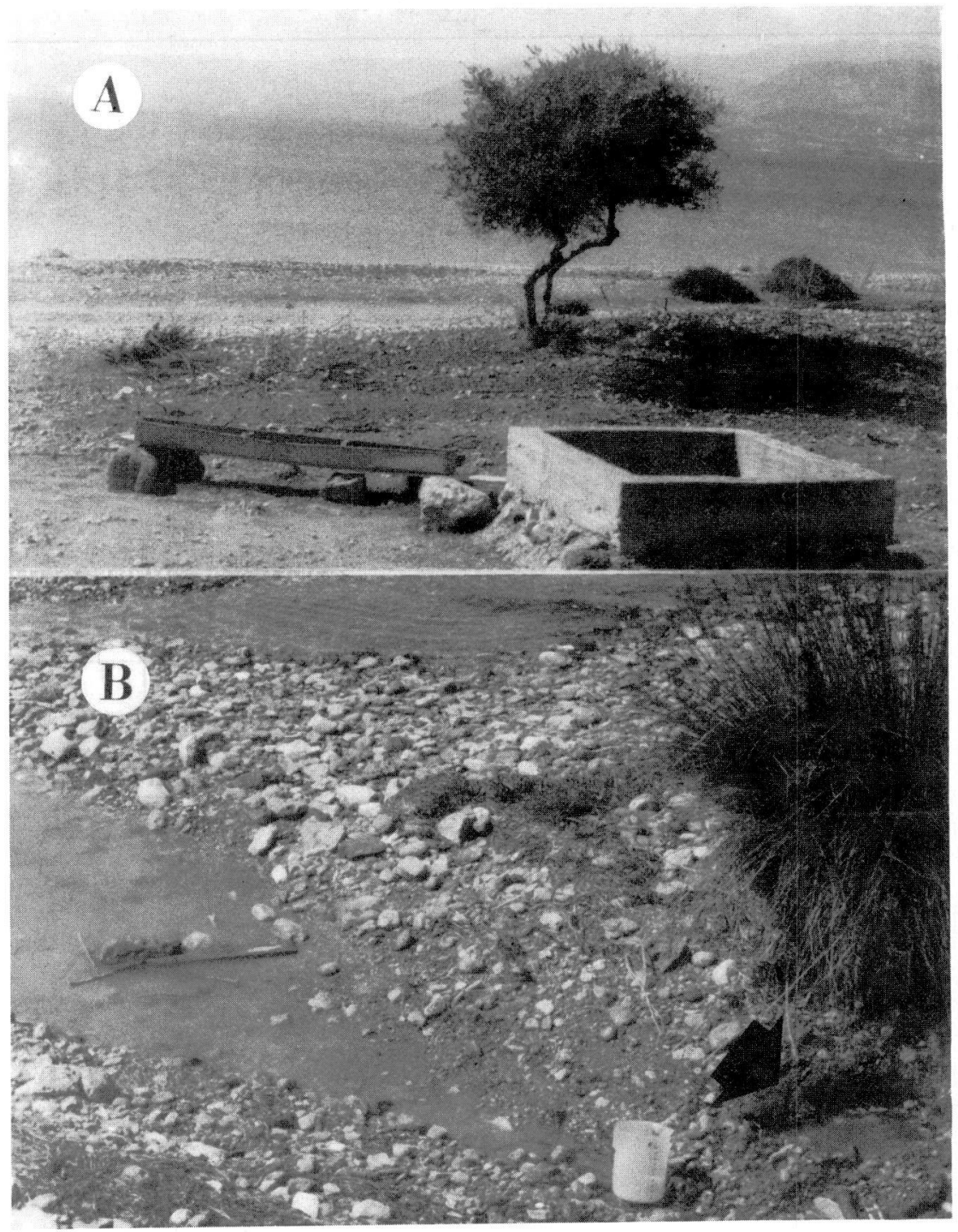

Fig. 3A. Site number 1 sampled using the Karamann-Chappuis' method. $B$. Well number 9, general view (see for location fig. 2). 
Table 1. The main characteristics of the sampling sites.

\begin{tabular}{|c|c|c|c|c|c|c|c|c|c|c|c|c|c|}
\hline $\begin{array}{c}\text { EUBOEA } \\
\text { sample } \\
\text { number }\end{array}$ & $\begin{array}{l}\text { (E) } \\
\text { I }\end{array}$ & II & III & IV & $\mathbf{v}$ & VI & VII & VIII & IX & $x$ & $\mathbf{X I}$ & XII & Fauna \\
\hline 1 & SL & 0.5 & $\mathrm{~K}-\mathrm{Ch}$ & $0.1 \cdot 0.2$ & $0.1-0.2$ & sa,pe,si & ++ & 29.46 & $27^{\circ}$ & - & - & - & $\mathrm{Hy}, \mathrm{E}$ \\
\hline 2 & SL & 0.5 & K-Ch & 0.1 & $0.1-0.2$ & sa,pe & + & 25.91 & $29^{\circ}$ & - & - & - & E \\
\hline . 3 & W & 19 & $C, C N, P N$ & 2.0 & 0.6 & a,pe & + & 0.09 & $19.5^{\circ}$ & UNU & $\mathrm{Co}^{* *}$ & - & $\mathrm{Hy}, \mathrm{E}$ \\
\hline 4 & W & $60-70$ & $\mathrm{PN}$ & 5 & - & ৭a & + & 0.14 & $19.5^{\circ}$ & Ga ir & Co ce & $\begin{array}{c}\mathrm{hPu} \\
\mathrm{m}+\mathrm{Pu}\end{array}$ & $\mathrm{Hy}$ \\
\hline 5 & W & $40-50$ & $\mathrm{CN}$ & 5.0 & 1 & sa & + & 0.13 & $?$ & Dr Wa & $\operatorname{Cos} \mathrm{x}$ & bu + & $\mathrm{Hy}, \mathrm{E}$ \\
\hline 6 & W & $80-100$ & $\mathrm{CN}$ & 7.8 & 0.5 & sa & + & - & $18^{\circ}$ & Dr Wa & Co ce & $\mathrm{mPu}$ & $\mathrm{Hy}$ \\
\hline 7 & W & $40-50$ & $\mathrm{CN}$ & $6-7$ & 1 & $?$ & + & - & ? & UNU & UCo & - & $\mathrm{E}, \mathrm{Hy}$ \\
\hline 8 & W & 30 & $\mathrm{CN}$ & 2.5 & 0.5 & ? & ++ & 0.07 & ? & Wa S & UCo & $?$ & $\mathrm{E}$ \\
\hline 9 & W & 300 & $\mathrm{CN}$ & 2.5 & 0.5 & $?$ & ++ & 0.08 & $?$ & Wa S & UCo & ? & $\mathrm{E}$ \\
\hline 10 & w & 20 & $\mathrm{CN}$ & 1.8 & 0.5 & a & ++ & 0.17 & ? & Wa S & UCo & ? & $\mathrm{E}$ \\
\hline 11 & W & 100 & $\mathrm{CN}$ & 2.0 & 0.8 & $\mathrm{mu}$ & +++ & 0.41 & $21^{\circ}$ & Ga ir & UCo & ? & $\mathrm{E}$ \\
\hline 12 & W & 20 & $\mathrm{CN}$ & 1.2 & 1 & ‘а & + & 0.08 & $22^{\circ}$ & Wa S & $\mathrm{UCo}$ & $?$ & $\mathrm{E}$ \\
\hline 13 & W & 50 & PN & $?$ & $?$ & $?$ & - & 1.27 & $19^{\circ}$ & Wa $S$ & Co ce & $\begin{array}{l}h \mathrm{Pu} \\
\mathrm{mPu}\end{array}$ & $\mathrm{Hy}$ \\
\hline 14 & $w$ & 60 & $\mathrm{CN}$ & 2.5 & 0.5 & $?$ & + & 0.57 & $\begin{array}{l}+++ \\
20^{\circ}\end{array}$ & Ga ir & UCo & $\mathrm{mPu}$ & $\mathrm{Hy}, \mathrm{E}$ \\
\hline 15 & $w$ & $150-200$ & $\mathrm{CN}$ & ? & $?$ & mu & +++ & 0.49 & ? & UNU & $\mathrm{UCo}$ & $-^{+}$ & - \\
\hline 16 & w & 50 & $\mathrm{CN}$ & ? & $?$ & a & - & 1.12 & ? & Ga ir & $\mathrm{COH}$ & $\mathrm{mPu}$ & - \\
\hline 17 & $w$ & 50 & $\mathrm{CN}$ & 4.0 & 1.0 & ? & + & $f \mathrm{cl}$ & $19^{\circ}$ & Dr $\mathrm{Wa}$ & UCo & $\begin{array}{l}+++ \\
\text { bu }+\end{array}$ & - \\
\hline 18 & w & $50-60$ & $C N$ & 2.5 & 0.5 & sa & - & $\mathrm{fcl}$ & ? & Dr Wa & Uco & $?$ & $\overline{\mathrm{Hy}}$ \\
\hline 19 & W & 30 & $\mathrm{CN}$ & 2.5 & 0.5 & $\mathrm{mu}$ & +++ & 0.17 & $21^{\circ}$ & UNU & UCo & - & $\mathrm{E}$ \\
\hline 20 & W & $30-40$ & $\mathrm{CN}$ & 2.5 & $0.3-0.4$ & $?$ & ++ & - & ? & UNU & $\mathrm{UCO}$ & - & $\mathrm{E}$ \\
\hline 21 & W & 30 & $C N$ & 2.5 & $0.3-0.4$ & $\mathrm{mu}$ & +++ & - & $?$ & UNU & UCo & - & $\mathrm{E}$ \\
\hline 22 & W & 80 & $C N$ & 4.0 & $?$ & $\mathrm{mu}$ & +++ & - & ? & UNU & Co p & - & $\mathrm{E}$ \\
\hline 23 & SL & 0.5 & $\mathrm{BR} \mathrm{Pu}$ & $0.1-0.2$ & 0.2 & sa & + & 20.59 & ? & - & - & - & $\mathrm{E}, \mathrm{Hy}$ \\
\hline 24 & SL & 1.0 & Sau & 0.1 & - & sa & + & - & - & - & - & - & $\mathrm{E}, \mathrm{Hy}$ \\
\hline 25 & SL & 1.0 & $\mathrm{~K}-\mathrm{Ch}$ & $0.1-0.2$ & 0.2 & sa & + & 17.75 & ? & - & - & - & $\mathrm{E}, \mathrm{Hy}$ \\
\hline
\end{tabular}

Legend for Table 1.

I - type of the habitat (S.L.-Supralittoral, W-well); Il - approximate distance from the seashore in meters; III - sampling method (K-Ch. -Karamann-Chappuis pits, C.N.-Cvetkov net, C-core, P.N.-plancton net, B.R.Pu. - Bou-Rouch pump, Saw.-sand washed); IV - depth of the grounwater table; V -depth under the groundwater table from which the fauna has been sampled; VI - type of sediment (sa.-sand, pe.-pebble, si.-silt, mu-mud); VII -organic matter $(+++$ large quantities, + + moderate, + little, $\rightarrow$ no); VIII - chlorinity in g/1, fcl-fresh cleaned; IX temperature of the water in degrees Celsius; $X$ - use of the wells (UNU-unused, Ga.ir.-garden irrigation, Dr. Wa.-drinking water supply, Wa.S.-water supply for the cattle); XI -protection of wells (Co-covered, + + very well, ce-cement, W-wood, Uco-uncovered, Cop-poor covered); XII - Extraction of water, methods and quantities (NPu-Norton handpump, mPu-motor pump, bu-bucket, + moderate extraction, +++ intensive extraction); XIII - Fauna (Hy-hypogean, E-epigean). 
the wells (number 4 and 16) I found marine fossil ostracods, foraminifers, and gastropods besides the coarse sand. A core of $10 \mathrm{~cm}$ depth in the sediment of well number 3 showed that the main fraction is constituted by coarse sand. All these facts suggest that on the western coast of Euboea the aquifer is developed in marine sediments.

Guernet (1971) showed that Euboea was connected with the main land during the Miocene and the Pliocene. South from Gialtra (at about $10 \mathrm{~km}$ from the village Aghios Georghios), Guernet found a lacustrine deposit with typical freshwater miocene gastropods (2 species of Melanopsis), which supports the idea that the northwestern part of Euboea has emerged at least since the Miocene. Psarianos and Thenius (1953) mentioned the presence of Elephas meridionalis near Aedipsos. This suggests to Guernet (1971) that the island was isolated from the mainland during the Pleistocene, later than the Villafranchian.

The extension and shape of the lowland coast of Euboea varied most probably during the Pleistocene due to the rise and fall of the sea level in the Aegean area. Marine quarternary sediments are registered in the Zarka Valley on the eastern coast of Euboea at about $10 \mathrm{~m}$ altitude (Guernet, 1971). Lüttig and Steffens (p. 47, 1977) noticed that during the Pleistocene "the most radical changes in the Aegean area occurred during Tyrrhenian. Large regions in the central and northern parts foundered and were flooded by the sea. A marine connection reached the Euxinic Basin via the Sea of Marmara.",

The 20 wells I investigated are located near the coast between 19 and about $200 \mathrm{~m}$ in from the seashore. Most of the wells are located at an altitude below $1 \mathrm{~m}$ above sea level. The water table lies at a depth of 2 to $8 \mathrm{~m}$ below the surface of the ground. The porosity seems to be low, at least around the Biological Station at Keramou (Matsakis, pers.comm.). The chlorinity of the water varies between $0.07 \mathrm{mg} / 1$ and $1.27 \mathrm{mg} / 1$. Thus, in all the wells there is freshwater (see Table 1). The temperature of the water in the wells varies between 19 and $22^{\circ} \mathrm{C}$.

I also investigated marine sediments near the seashore in the supra littoral area and/or near the upper limit of the tide in the intertidal zone. The range between low and high tide levels represents about $6 \mathrm{~m}$. The chlorinity varies between 17.45 and $29.46 \mathrm{~g} / 1$.

The marine interstitial fauna have been collected using a BouRouch pump, digging pits and filtering the water (the Karaman-Chappuis' method). In these cases I extracted 5 liters of water. In one case I washed moist sand (1-2 liters; see table 1).

There are two types of wells: (1) Largely cased wells with a diameter of about 1-1.5 m (seldom $2 \mathrm{~m}$, well number 6 ), and (2) Norton pumps. The former have been sampled from outside with a Cvetkov net and sometimes inside with a plankton net. The latter have been sampled by filtering the pumped water through a plankton net (mesh $80 \mu \mathrm{m})$. All the samples are qualitative.

Most of the wells contain meio- and macrofauna. The 20 wells can be grouped into 6 types:

I - Norton pumps $(4,13)$ which are still in use and provide water for in- 
habitants. The water is clean and contains little particulate organic matter.

II - Large wells covered and well protected such that little organic matter accumulates from outside; the bottom is periodically cleaned. The water is used for drinking and is extracted moderately, sometimes using a motor pump. Such wells are number 5, 6, 17, and 18 .

III - Large wells which are no longer in use but are covered so that little pollution comes from outside (number 3 is an example).

IV - Large wells which are currently in use, the water being strongly pumped (with motor devices) for the irrigation of land and orchards (see well number 16).

V - Large uncovered wells, moderately used for irrigation; organic matter accumulates on the bottom (see well numer 14).

VI - Large wells, mainly uncovered, which are seldom in use for supplying water for the cattle, or which are no longer in use. Much organic matter accumulates on the bottom, which is muddy. The water temperature of these wells is $1-2^{\circ} \mathrm{C}$ higher than in the protected wells used for the drinking water supply. Such wells are numbers 7, 8, 9, 10, 11, 15, 19, 20, 21, 22.

\section{RESULTS (tables 1-3)}

The Norton pumps and the well which is intensively used for irrigation (the wells of type 1 and type 4 in table 2) contain no ostracods. This seems to be incidental in the type 1 wells as other hypogean animals could be found (Isopods, Microcerberus, and harpacticoids). No animals were found in type 4 wells, which might be a result of intensive pumping. The group of wells of type 2 and type 3 , considered as clean or slightly polluted, contain two interstitial (hypogean) ostracods: Mixtacandona pseudocrenulata described by Schäfer (1945) and Pseudolimnocythere hartmanni, a new species (see Danielopol, 1979).

The group of wells of type 5 and 6 with polluted bottoms contains mainly epigean species. Cypria lacustris Sars is the most abundant and the most common species in these wells (see table 2). It is followed by Cypridopsis newtoni (Br. and Rob.). Both species have been recorded by Stephanides (1948) in the wells of Corfu (see well number P 53a). Cypria lacustris occurs commonly in wells in Yugoslavia (Petkovski, 1976), in Romania (Danielopol, 1965), but also in epigean habitats (Petkovski, 1960). The carapace shape, the male copulatory organ, and the female genital lobe of the specimens from Euboea conform to those described by Petkovski (1960). Cypridopsis newto$n i$ seldom occurs in wells but is encountered mainly in permanent fresh or oligohaline water bodies, especially during summer and autumn (Klie, 1938 and 1941).

Besides Cypria lacustris, isolated specimens of Ilyocypris bradyi Sars occurred in the wells number 8 and 9. Many empty carapaces of Ilyocypris can also be found on the bottom of those wells. This suggests that in those wells where Cypria lacustris is predominant processes of competition with Ilyocypris bradyi could occur, finally affecting the exclusion of this latter ostracod. 
Table 2. Distribution of the ostracod fauna in the Euboea wells (numbers 3-22); I-VI type of wells (see text). The broken line delineates the main ostracod associations.

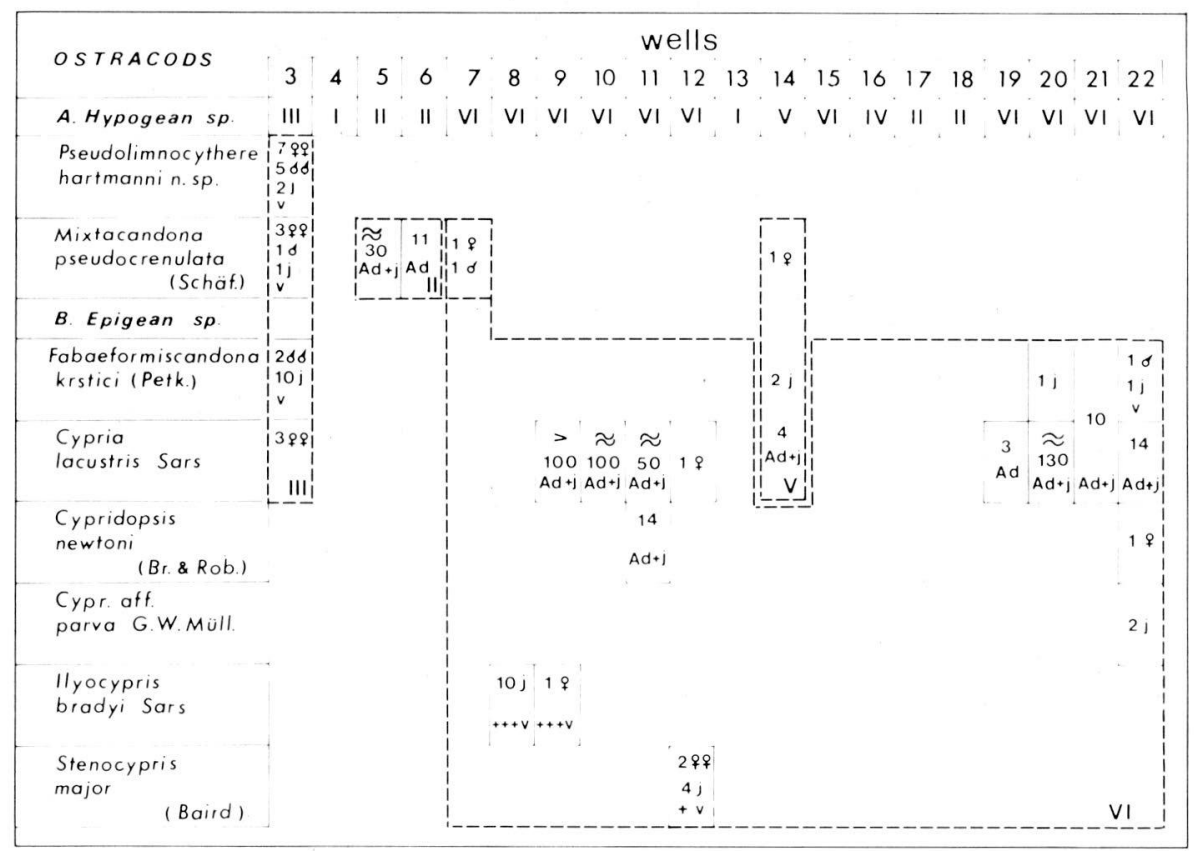

Fabaeformiscandona krstici (Petkovski, 1969) is an epigean species which has been described using living material from Ochrid Lake, Yugoslavia. Petkovski considers that this species also occurs in the Pleistocene deposits of the Liri Valley (see Devoto, 1965). The species is recorded in Greece for the first time.

Stenocypris major (Baird) is an epigean thermophilic species which has already been recorded in South and Central Europe (see Löffler and Danielopol, 1978). This species is recorded for the first time in a well (number 13) in Greece.

The wells of Euboea behave like island habitats, colonized by both epigean and hypogean species. The diversity is low. I used the Brillouin index for the ostracods, which follows the suggestion of Kaesler and Mulvany (1977, p. 33): “Brillouin's equation from information theory is well suited for studying diversity and community structure of recent and fossil ostracods. This equation gives the actual diversity per individual in a collection and not an estimate of the parametric diversity of an statistical universe. Because of the difficulties of defining the extent of the statistical universe from which samples of ostracods are drawn, study of collections in their own sake 
is to be prefered.' For instance, for well number 3, the Brillouin's diversity index is 0.48 (table $3 \mathrm{~B}$ ).

In shallow marine habitats of Baja California, Kaesler and Mulvany (1977) recorded a diversity index of the ostracod associations varying between 0.45 and 2 .

The wells that are uncovered are protected very little against the pollution from outside and those from which water is pumped intensively constitute ecologically unstable habitats.

Table 3A. Distribution of marine interstitial ostracods in the investigated area.

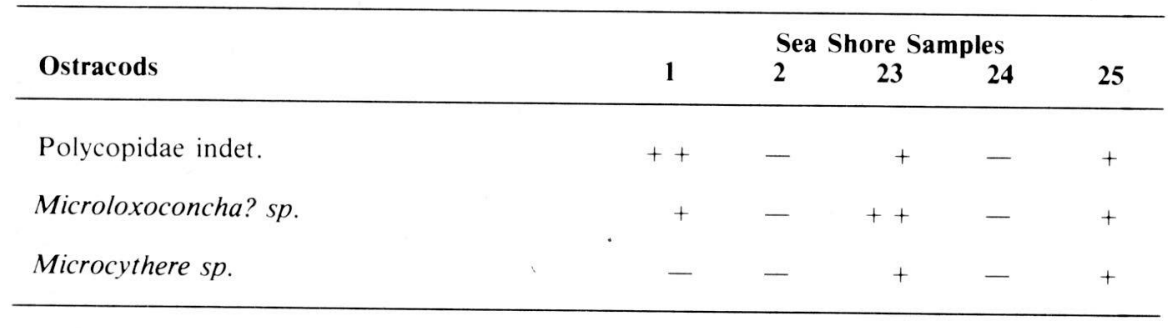

1,2,23-25 number of the sample sites (see table 1 e fig. 2 );

,+++ abundance of the ostracod species (see text also).

Table 3B. The ratio between hypogean and epigean ostracod species as percentage in wells 3,5 , 14,16 , and 22 .

\begin{tabular}{lccccc}
\hline Wells & 5-II & 3-III & 16-IV & 14-V & 22-VI \\
\hline Hypogean / Epigean $\%$ & $100 /$ & $56 / 44$ & 0 & $14 / 86$ & \\
$\mathrm{H}_{\text {Brillouin }}$ & & 0,48 & & \\
\hline
\end{tabular}

$\mathrm{H}_{\text {Brillouin }}$ - the diversity index computed (using the Brillouin's expression for the ostracod association of well number 3 . 
In the polluted wells (e.g., well number 22), the fauna are represented by epigean cosmopolitan forms: ostracods (Cypria lacustris), isopods (Asellus aquaticus), Culicidae and Chironomidae larvae which penetrate from outside.

In the unprotected wells from which water is taken moderately (e.g., well number 14), the abundance of the epigean fauna is higher than those of the hypogean, see ostracods in tables 2 and $3 \mathrm{~B}$.

In protected wells (covered outside) no longer in use, such as well number 3, the hypogean animals are more abundant than the epigean ones (tables 2 and 3B). Finally, in the protected wells used for drinking water supply (like the Norton pumps and well number 5), no epigeans are found (for the ostracods, see table 2 and 3B).

Ronneberger (1975) suggests that the ratio between the epigean and hypogean animals in the wells could be used as an index for their water quality. The present investigation confirms the validity of this assumption.

The interstitial ostracods found in the supralittoral near the upper limit of the tide level (sites 1, 23, and 25) are represented by a species belonging to the family Polycopidae and the interstitial species Cytheracea belonging to the genera Microloxoconcha? and Microcythere. These three ostracod groups have exclusively marine representatives. Most of them live in porous sediments of the littoral and the supralittoral zones (Hartmann, 1973).

At site 1 (see fig. 3A), the sediment consists of coarse sand and pebbles. The Polycopidae predominate characterized by long "swimming" antennal setae, whereas the creeping form Microloxoconcha? is rare. At sites 23 and 25 , the beaches have only coarse sand. In this habitat I found more Microloxoconcha? sp. and seldom Microcythere (another creeping form) and Polycopids.

The lack of freshwater ostracods (Cyprididae) mixed with these marine ostracods in the interstitial habitats near the seashore is striking. This could be due to the fact that the zone where subsurface marine and freshwaters mix is very narrow and does not allow the coexistence of freshwater and marine forms in some transitory brackish water environment as portrayed by Delamare-Deboutteville (1960). A similar pattern is displayed by other meioand macrofauna. At site 24, the marine interstitial halacarid Acarochelopodia sp. aff. delamarei occurs and the freshwater halacarid Lobohalacarus quadriporus is found in well number 3. Sample 24 also contains many Hesionides arenaria, Fried., a typical marine interstitial polychaet living in fine and coarse sands. The halacarids have been identified by Dr. T. Gledhill and the polychaets by Dr. L. Laubier.

One has to note the limited number of freshwater hypogean ostracod species (two species only) in the investigated area (about $15 \mathrm{~km}$ along the coast). It is often postulated that the groundwater habitats are highly stable and have a long temporal permanency (see interalia, Noodt, 1968).

In such time-stable habitats, a high diversity of fauna could develop (see the Sanders' stability-time hypothesis with examples from deep sea and Baikal Lake habitats; Sanders, 1969).

The northwestern coast of Euboea has a porous aquifer in the lowland 
which was most probably affected by the sea level fluctuations during the Pleistocene. If this view is accepted, the habitat I investigated does not have the time-stability attribute.

The low effective porosity seems to be responsible for the small size of the hypogean fauna (ostracods of 0.3-0.5 mm length). The presence of $\mathrm{Mi}$ crocharon (very common), Microcerberus, Ingolfiella petkovskii, Bogidiella skoplensis*, and the lack of larger Malacostraca, and hypogean Ostracoda like Niphargus, representatives, Proasellus sketi Henry, Pseudocandona and Candonopsis species, is striking.

A higher diversity of hypogean fauna can be expected in Greece on the mainland in habitats with a better porosity and a longer permanency. Such a habitat could be the porous aquifer of the Ladon Valley (station Gr.5, fig. 1) in Arcadia, where Bou (1975) found 5-6 species of hypogean amphipods in one place.

Finally, these data suggest that in the Mediterranean area the hypogean fauna could be easily found in protected wells, with little organic matter accumulated and where water is pumped moderately. This observation should be of some help to those who are interested in faunistic surveys. They always face the problem of selecting the wells that should be sampled with the hope of finding a rich hypogean fauna.

\section{CONCLUSIONS}

1) Mixtacandona pseudocrenulata, one of Schäfer's species found in Thessaly, was found in the porous aquifer of Euboea, which partly confirms my suspicion that the ostracods described by Schäfer live in an interstitial habitat.

2) The large wells in Euboea behave like island habitats which are colonized by both epigean and hypogean animals.

3) The hypogean ostracods live mainly in protected wells with little organic matter accumulation, where water is pumped moderately. The epigean ostracods predominate in uncovered wells with polluted water and rich inorganic matter.

4) The ostracod species found in some of the Euboea wells, like number 3 , form coherent associations in which the epigean species could be as important as the hypogean ones.

5) The data presented above reinforce the suggestion of Ronneberger (1975) that the ratio between epigean and hypogean animals in wells could be used as an environmental index to show the degree of pollution in the wells. Further investigations are needed to demonstrate how the pollutants and/or epigean fauna eliminate hypogean fauna from wells.

6) The low number of hypogean ostracods in the area investigated could be due either to the instability of the well habitats on an ecological time scale

* Species found in Greece for the first time (det Cl. Bou). 
or to the instability of the coastal aquifer at an evolutionary time scale.

7) The presence of exclusively small size hypogean ostracods could be due to the fine grained sediment.

8) There is a sharp difference between the marine interstitial ostracods found in the supralittoral zone of the Euboea coast and those of the wells inland.

9) Finally, these data suggest that in the Mediterranean realm the hypogean fauna could be found easily in wells with little accumulation of organic matter, where water is pumped moderately.

\section{ACKNOWLEDGEMENTS}

I am greatly indebted to the following colleagues who helped during the completion of this project: J. Th. Matsakis, director of the Biological Station Keramou, Cl. Bou (Albi), N. Coineau (Banyuls s. Mer), T. Gledhill (East Stoke), Cl. Guernet (Paris), J.-P. Henry (Dijon), Fr. LecherMoutoué (Moulis), L. Laubier (Brest), H. Löffler (Wien), F. Rögl (Wien), R. Rouch (Moulis), F. Steiniger (Wien) and P. Steffens (Hannover).

\section{RÉSUMÉ}

La faune dulçaquicole de 20 puits localisés à 15-200 mètres du rivage, de même que la faune marine interstitielle, ont été prospectées dans la zone côtière autour du village Aghios Georghios (Cap Likhada, île d'Eubée). Les Ostracodes hypogés d'eau douce vivent principalement dans les puits couverts, dont le fond est propre et pauvre en matiéres organiques et dont l'eau est pompée modérément. Les Ostracodes épigés d'eau douce prédominent dans les puits à l'air libre, avec de grandes quantités de matière organique sur le fond. Une différence accusée existe entre la faune ostracodologique vivant en eaux douces souterraines (principalement des Cyprididés) et celle des habitats interstitiels marins côtiers (Cythéridés et Polycopidés marins). On peut penser que dans le domaine méditerranéen, la faune hypogée pourrait être le plus aisément découverte dans les puits couverts, où l'accumulation de matière organique est faible et dont l'eau est modérément pompée.

\section{REFERENCES}

BOU, Cl. 1974. Observations sur les Ingolfiellides (Crustacés Amphipodes) de Grèce. Biol. Gallo.-Hellen. 2(1):57-70.

BOU, Cl. 1975. Rechèrches sur la faune des eaux souterraines de Grèce. Biol. Gallo.-Hellen. 6(1):101-116.

COINEAU, N. 1969. Isopodes interstitiels de l'île d'Eubée, Grèce. Biol. Gallo.-Hellen. 3(1):99103.

DANIELOPOL, D. 1965. Nouvelles données sur les ostracodes d'eau douce de Roumanie. Ann.Limnol., Toulouse, 1:443-468.

DANIELOPOL, D. 1971. Quelques remarques sur le peuplement ostracodologique des eaux douces souterraines d'Europe, in: Paléoécologie des ostracodes, OERTLI H.J., Ed., Bull. Centre Rech.S.N.P.A., Pau, suppl. 5:179-190.

DANIELOPOL, D. 1977. On the origin and diversity of European freshwater interstitials ostracods, in: Aspects of Ecology and Zoogeography of Recent and Fossil Ostracoda, LÖFFLER H. and DANIELOPOL D. Eds., Junk BV, The Hague: 295-305.

DANIELOPOL, D. 1979. On the origin and the antiquity of the Pseudolimnocythere species (Ostracoda, Loxocondidae), in: The 1st Congress on Ecology and Zoogeography of Greece, MATSAKIS, J., Ed., Biol. Gallo.-Hellen. 8:99-107. 
DELAMARE-DEBOUTTEVILLE, Cl. 1960. Biologie des eaux souterraines littorales et continentales. Hermann, Paris.

DEVOTO, G. 1965. Lacustrine Pleistocene in the lower Liri Valley Southern Latium. Geologia Romana 4:29-368.

GUERNET, Cl. 1971. Études géologiques en Eubée et dans les régions voisines (Grèce), Thèse, Univ. Paris.

HARTMANN, G. 1973. Zum gegnwärtigen Stand der Erforschung der Ostracoden interstitieller Systeme. Ann. Spéléol. 28,3:417-426.

KAESLER, R.L. and MULVANY, P.S. 1977. Approaches to the diversity of assemblages of Ostracoda, in: Aspects of Ecology and Zoogeography of Recent and Fossil Ostracoda, LÖFFLER H. and DANIELOPOL D. Eds., Junk BV, The Hague: 33-44.

KLIE, W. 1938. Ostracoda, Krebstiere oder Crustacea III, Muschelkrebse, in: Die Tierwelt Deutschlands, DAHL, 37:1-230.

KLIE, W. 1941. Süßwasserostracoden aus Südosteuropa. Zool.Anz. 133,11/12:233-244.

LÖFFLER, H., and D. DANIELOPOL. 1978. Ostracoda, in: Limnofauna Europaea ILLIES J., Ed., G. Fischer Verl., Stuttgart:196-208.

LÜTTIG, G., and P. STEFFENS. 1977. Explanatory notes for the paleogeographic atlas of Turkey from the Oligocene to the Pleistocene. Hannover:1-64.

MATSAKIS, J.Th. 1975. Apercu général sur la région et premier bilan relatif à la faune terrestre et dulcaquicole. Biol. Gallo.-Hellen. 6,1:117-124.

NOODT. W. 1968. Deuten die Verbretungbilder reliktärer Grundwasser-Crustaceen alte Kontinent-Zusammenhänge an?. Naturw. Rdsch. 11:470-476.

PETKOVSKI, T. 1960. Zur Kenntnis der Crustaceen des Prespasees. Fragm. Mus. Maced. Sc. Nat. 3,15:117-131.

PETKOVSKI, T. 1969. Einige neue und bemerkenswerte Candoninae aus dem Ohridsee und einigen anderen Fundorten in Europa (Crustacea-Ostracoda). Acta. Mus. Maced. Sc. Nat. 11,5:81-110.

PETKOVSKI, T. 1976. Zwei neue und eine seltene Ostracoden-Art der Gattung Cypria Zenker aus Jugoslawien. Acta. Mus. Maced. Sc. Nat. 14, 7:173-192.

PSARIANOS, P., and E. THENIUS. 1953. Über Elephas (Archidiskodon) meridionalis (Eleph. Mammal) von Euböa (Griechenland). Prak. Akad. Ath. 28:413-424.

RONNEBERGER, D. 1975. Zur Kenntnis der Grundwasserfauna des Saale-Einzugsgebietes (Thüringen). Limnologica (Berlin) 9,3:323-419.

SANDERS, H. 1969. Benthic marine diversity and the stability time hypothesis, in: Diversity and Stability in ecological systems, Brookhaven Symposia in Biology WOODWELL C. and SMITH H., Eds. Springfield, nr. 22:71-81.

SCHÄFER, H.-W. 1945. Grundwasser-Ostracoden aus Griechenland. Arch.f.Hydrobiol. 40,4: $847-866$.

SCHÄFER, H.-W. 1951. Über die Besiediung des Grundwassers. Verh. Int. Verein. Theor. Ang. Limnol. 11:324-330.

STEPHANIDES, Th. 1948. A survey of the freshwater biology of Corfu and of certain other regions of Greece. Publ. Hellen. Hydrobiol. Inst. II. 2:1-251.

YANNOPOULOS, C., and J.-M. BARROIS. 1975. Ecologie marine de la région d'Eubée du Nord. I Donées préliminaires sur le zooplancton et l'ichthioplancton. Biol. Gallo.-Hellen. 6,1:125-134. 